\title{
Tung Oil Production in Florida ${ }^{1}$
}

\author{
Patrick Minogue ${ }^{2}$
}

Historically, tung tree (Aleurites fordii Hemsl.) oil production occurred within a 75- to 100-mile-wide belt through the Gulf Coastal Plain, from east Texas to Georgia and south into the Florida Gainesville area (Snow 2013). Tung trees are native to central and western China and are grown for their nuts, which contain $30 \%-40 \%$ high-quality, quickdrying oil used in the manufacture of lacquers, varnishes, paints, linoleum, resins, artificial leather, brake linings, and electronics insulation, to name a few (Duke 1983). Commercial tung oil production in the southeastern United States began with the first commercial processing plant in 1927 and increased rapidly from 1,000 tons produced in 1939 to 132,000 tons in 1952, yielding 42 million pounds of oil in this year of peak production (Potter and Crane 1957). There were 13,961 acres of Florida tung tree plantations in 1969, comprised of 42 farms, predominately in Jefferson, Jackson, and Leon Counties (Snow 2013). A series of years with late-winter freezing temperatures and damage from Hurricane Camille resulted in the abandonment of commercial tung tree production in the Southeast (Robb and Travis 2013).

Presently, there is renewed interest in tung tree production in north Florida to help meet the demand for tung oil as a wood finish (Aleman 2014). Interest is also bolstered by the development of a later flowering cultivar 'Spiers', and more moderate winter temperatures occurring throughout the Southeast. Historically, cold injury to floral buds has been one of the greatest hazards in tung production (Spiers and Kilby 1973). The buds are formed by the late fall and have a chilling requirement of $260-360$ hours at $45^{\circ} \mathrm{F}$ or below. After they have received their chilling requirement, buds will break dormancy following warm weather periods in late winter or early spring. At full bloom, temperatures of $29^{\circ} \mathrm{F}$ can kill floral buds. 'Spiers' flowering is estimated to be 2 weeks later than other commercial cultivars, making it less vulnerable to late frost injury (Rinehart et al. 2015). The unpatented 'Spiers' was released by the USDA Agricultural Research Service. It is expected that $80 \%$ to $95 \%$ of seed from open-pollinated mother plants should perform true to type, while growth habit, fruit production, and oil production are comparable or superior to older cultivars (Spiers and Kilby 1973; Rinehart et al. 2015).

\section{Description}

Tung is a fast-growing deciduous tree species and can grow to $40 \mathrm{ft}$ in height, with smooth bark and soft wood. Leaves are heart shaped, sometimes lobed, dark green and up to 6 or more inches wide. Flowers are produced in early spring, before foliage. Blooms are attractive, white with a rose-colored center and are borne in clusters from terminal shoots from the previous growing season. Fruits are spherical or pear-shaped, green to purple at maturity and contain 4 to 5 seeds. Seeds have a hard shell and a large endosperm from which tung oil is extracted. Tung oil is largely comprised of $75 \%-80 \%$ a-elaeo stearic, $15 \%$ oleic, and circa $4 \%$ palmitic

1. This document is FOR351, one of a series of the School of Forest Resources and Conservation, UF/IFAS Extension. Original publication date October 2019. Visit the EDIS website at https://edis.ifas.ufl.edu for the currently supported version of this publication.

2. Patrick (Pat) Minogue, associate professor of Silviculture, School of Forest Resources and Conservation, UF/IFAS North Florida Research and Education Center, 155 Research Rd, Quincy, FL 32351.

We are grateful for funding from the Florida Department of Agriculture and Consumer Services, Office of Agricultural Water Policy, in support of our research and Extension activities to protect water resources quality and quantity.

The Institute of Food and Agricultural Sciences (IFAS) is an Equal Opportunity Institution authorized to provide research, educational information and other services

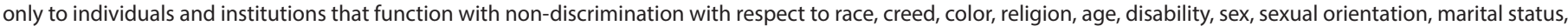

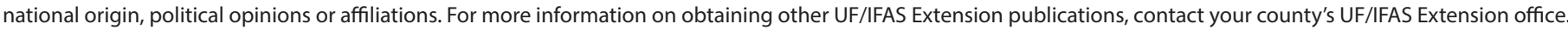
U.S. Department of Agriculture, UF/IFAS Extension Service, University of Florida, IFAS, Florida A \& M University Cooperative Extension Program, and Boards of County Commissioners Cooperating. Nick T. Place, dean for UF/IFAS Extension. 
oils (Duke 1983). All parts of the tung trees are poisonous, and the seeds are highly toxic to humans and animals.

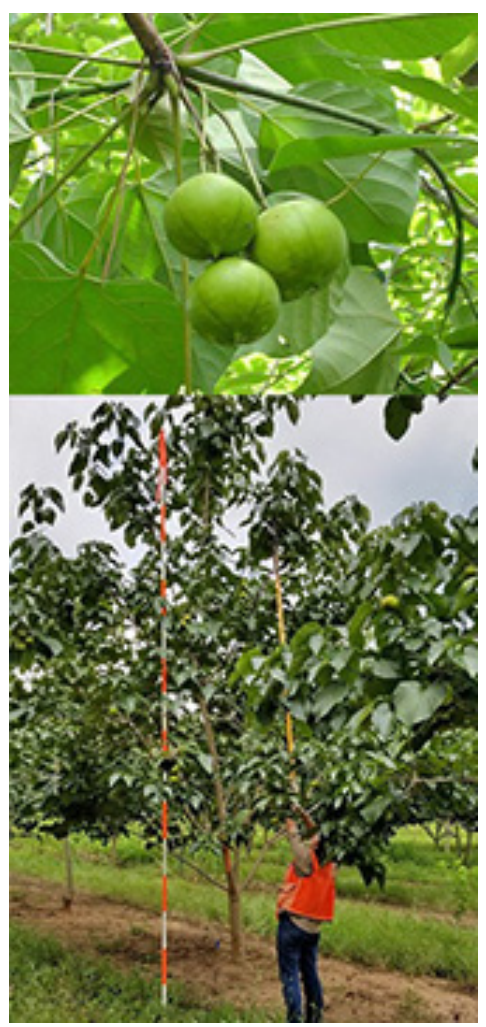

Figure 1. Tung tree (Aleurites fordii) showing the fruit (left) and our "Best Management Practices" (BMPs) research in Leon County, Florida, during foliar nutrient sampling in August 2018 (right).

\section{Ecology}

Tung trees are very exacting in climatic and soil conditions. Trees grow best if planted on hilltops or slopes because good air drainage reduces losses from spring frosts. They require good soil fertility and well-drained loamy sands, such as the Ruston, Orangeburg, Red Bay and Norfolk series in Florida.

Tung tree is listed by the UF/IFAS Assessment of NonNative Plants as low risk for invasion, with caution in the north zone to manage to prevent escape. It has naturalized in north and central Florida and in other Gulf states where it was cultivated.

\section{Cultivation}

Nursery stock may be grown from seed (generative) or by grafting high-producing selections onto seedling rootstock (vegetative). In young orchards desired selections may be grafted onto established seedlings (budding) to improve yield (Duke 1983). Tung seeds are short-lived and should be planted during the dormant season or the spring following harvest. The seeds should be removed from the hull within the shell and air-dried before planting. Hulled seed may be planted dry, but soaking seeds in cold water for five to seven days before planting hastens germination.

In nursery production, stratification in aerated, cold water or moist medium at $45^{\circ} \mathrm{F}$ or chemical treatment (dilute acid) increases the rate and uniformity of emergence. Duke (1983) recommended planting dry seeds no later than February, stratified seed by mid-March, and chemically treated seed by early April. Seeds may be planted in nursery beds by hand or using a modified corn planter set at a 2 -inch depth. Seeds are spaced 6 to 8 inches apart, with rows $5 \mathrm{ft}$ apart. Seeds germinate in 60 days or more, necessitating weed control. The development of selective herbicide options for tung tree production is a priority research need.

Nursery-produced rootstocks are planted into the orchard during the dormant season, optimally from December to the end of February. In contour-planting the number of trees and spacing on the row and between rows vary depending upon the slope, but trees 11 to $13 \mathrm{ft}$ apart in rows 33 to $39 \mathrm{ft}$ apart results in 100-142 trees per acre. In past practices, transplanted nursery stock was pruned back to 8- to 10-inch height at planting, but at present, optimum pruning practices at various ages remain an important research question.

Soils in the Florida tung belt are slightly to strongly acid, typically ranging from $\mathrm{pH} 5.0$ to 6.5. Tung requires a moderately acid soil, but it is often recommended to lime acid soils to $\mathrm{pH}$ 6.0. This will increase available phosphorus and potentially cation exchange from soil colloids. Additionally, if leguminous cover crops are grown in a tung orchard, such as clover, they will perform better at $\mathrm{pH} 6.0$ to 6.5 . In nursery production, Duke (1983) recommends a side dressing of nitrogen $(\mathrm{N})$, phosphorus $(\mathrm{P})$, and potassium $(\mathrm{K})$ fertilizer, in a band 8 inches from seedlings on each side of the row to supply $530 \mathrm{lb} /$ acre 5-10-5 (N:P:K) as soon as seedlings emerge. Potter and Crane (1957) recommend significant annual $\mathrm{N}, \mathrm{P}_{2} \mathrm{O}_{5}$, and $\mathrm{K}_{2} \mathrm{O}$ inputs (140-160, 60 and $200-250 \mathrm{lb} / \mathrm{acre}$, respectively) to optimize nut production in bearing tung orchards. Experience with orchards of nut-bearing trees, such as pecans, suggests that increased fertilizer use efficiency is fostered by split applications at six-week intervals, timed when rainfall is expected.

A composite soil sample should be taken before establishing a tung orchard to determine inherent fertility and site suitability. Soil tests are useful for helping to identify potential nutrient deficiencies, but including foliar sampling provides additional information about what was taken up by the trees. Potter and Crane (1957) published critical 
ranges for nutrient concentrations in tung leaves (Table 1). Our current research is verifying these critical nutrient guidelines and elucidating $\mathrm{N}$ and $\mathrm{P}$ fertilization regimes in new and established orchards to help develop Tung "Best Management Practices" (BMPs).

Table 1. Critical ranges for nutrient elements in tung leaves sampled in late July or early August. ${ }^{1}$

\begin{tabular}{|l|c|c|}
\hline \multicolumn{1}{|c|}{ Element } & $\begin{array}{c}\text { Calculated as } \\
\text { elemental }\end{array}$ & $\begin{array}{c}\text { Leaf dry weight } \\
\text { composition }\end{array}$ \\
\hline Nitrogen & $\mathrm{N}$ & $\mathbf{( \% )}$ \\
\hline Phosphorus & $\mathrm{P}$ & $2.00-2.50$ \\
\hline Potassium & $\mathrm{K}$ & $0.14-0.20$ \\
\hline Calcium & $\mathrm{Ca}$ & $0.70-1.00$ \\
\hline Magnesium & $\mathrm{Mg}$ & $1.00-2.50$ \\
\hline & & $0.25-0.35$ \\
\hline Copper & $\mathrm{Cu}$ & $\mathbf{( p p m )}$ \\
\hline Manganese & $\mathrm{Mn}$ & $4-5$ \\
\hline Zinc & $\mathrm{Zn}$ & $50-100$ \\
\hline 1 & & $25-35$ \\
\hline
\end{tabular}

${ }^{1}$ From Potter and Crane 1957.

\section{Tung Oil Production}

Tung trees typically begin bearing fruit the third year after planting and may be commercially productive by the fourth or fifth year, under intensive culture. Maximum production occurs by the $10^{\text {th }}$ to $12^{\text {th }}$ year, and trees live approximately 30 years (Duke 1983). Fruits mature in late September and early November and fall to the ground. They are collected when the shells become brittle and dark, 3 to 4 weeks or more, and moisture content falls below $30 \%$. In past practices, the fruits were placed in sacks and placed in the crotches of the trees to dry. Fruits must be dried to $15 \%$ moisture content before they are processed for oil extraction (Potter and Crane 1957). At peak production, tung orchards typically produce 2 to 2.1 tons of fruit per acre that contains $18.5 \%$ to $20 \%$ oil content by weight (Duke 1983).

\section{Summary}

Tung tree seed is a potential alternative crop in northern and central Florida on sites having relatively well-drained, fertile soils and adequate moisture. Tung trees are fastgrowing and produce a high-value oil that is in demand for furniture finishing and other uses. Much of the information regarding tung orchard management and oil production was published in the 1950s or earlier when it previously was a commercial oil crop in the region. A review of the literature suggests these priorities for additional research:
- Examine macro- and micro-nutrient fertilization requirements for optimal tree growth, nut yield, and oil content.

- Verify critical foliar nutrient concentrations (Table 1) for optimum tree growth, nut production, and oil content.

- Develop efficient fertilization BMP guidelines for tung tree cultivation in the Gulf Coast region.

- Develop selective weed control practices for nursery stock production and orchard establishment.

- Determine optimum orchard density and pruning systems for improved nut harvest and tung oil yield.

- Continue phenotype selection and breeding for improved varieties.

\section{Literature Cited}

Aleman, L. 2014. Why the tung oil industry might be making a comeback. 850 Business magazine. 5 Pp.

Duke, James A. 1983. Handbook of Energy Crops. Purdue University Center for New Crops \& Plants Products. http:// www.hort.purdue.edu/newcrop\%20/duke energy/Aleuritesfordii.html

Potter, G. F., and H. L. Crane. 1957. Tung production. U.S. Department of Agriculture Farmer's Bulletin no. 2031. Washington D.C. 35 Pp.

Rinehart, T., J. Shockey, N. Edwards, J.M. Spiers, and T. Klasson. 2015. "Vernicia fordii 'Spiers', a new tung tree for commercial tung oil production in the Gulf Coast Region." HortScience 50(12):1830-1832.

Robb, J. B., and P. D. Travis. 2013. "The rise and fall of the tung oil industry." Forest History Today (Spring/II 2013). Pp $14-22$.

Snow, W. A. 2013. Tung tried: agricultural policy and the fate of a Gulf South oilseed industry, 1902-1969. Ph.D. Dissertation. Mississippi State University. 403 Pp.

Spiers, J. M., and W. W. Kilby. 1973. Evaluation of lateblooming tung selections. Mississippi Agricultural \& Forestry Experiment Station. Information Sheet 1219. 2 Pp.

UF/IFAS. 2019. Assessment of Non-Native Plants. Aleurites fordii. https://assessment.ifas.ufl.edu/assessments/aleuritesfordii/ accessed August 23, 2019 